\title{
PROPUESTA DE UN PLAN DE GESTIÓN AMBIENTAL DE LA DISPONIBILIDAD DEL RECURSO HIDROGEOLÓGICO CON RELACIÓN AL ABASTECIMIENTO DE AGUA EN EL ESPACIO COSTERO DE EL COCO. CARRILLO, GUANACASTE. COSTA RICA
}

\author{
Lidia Orias (2011)
}

La presente investigación se realizó en el espacio costero de El Coco, del distrito Sardinal del cantón de Carrillo, de la provincia de Guanacaste.

El área de estudio se asienta en el acuífero El Coco, que presenta un acelerado crecimiento urbano, enfocado en la actividad turística, que ha incrementado la presión por el recurso hídrico, debido a los cambios en el uso de la tierra, por el aumento de actividades económicas, que paralelamente han favorecido la extracción de agua de pozos privados sin regulación. Esta realidad ha provocado una alta vulnerabilidad a la contaminación del acuífero costero El Coco.

No existen investigaciones antecedentes sobre planes de gestión ambiental de la disponibilidad del recurso hidrogeológico, con relación al abastecimiento de agua en el espacio costero de El Coco, ni en otros distritos del cantón de Carrillo, por ello, la presente investigación es de tipo diagnóstica exploratoria.

Se utilizaron fuentes secundarias para realizar un análisis de las características geológicas e hidrogeológicas del área de estudio, asimismo para efectuar un análisis histórico del uso de la tierra, a fin de investigar el proceso de construcción y transformación del espacio costero de El Coco. Se aplicó la técnica de fotointerpretación de fotografías aéreas de los años: 1947, 1971, 1998 y de teledetección a partir de imágenes satelitales de año 2007, además del levantamiento in situ de coordenadas con GPS del año 2009, para obtener una secuencia de cuatro mapas de Uso de la tierra (1947, 1971, 1998 y 2009), con la utilización de SIG.

Se utilizaron encuestas estructuradas y abiertas como fuentes primarias para obtener información acerca del uso y la gestión del agua en El Coco, dirigida a usuarios del servicio de agua potable y dirigentes locales.

En esta investigación se evaluó el estado del marco legal del recurso hídrico en el espacio costero de El Coco, así como el uso del recurso hídrico. Se identificó y caracterizó las redes de pozos potencialmente vulnerables a la contaminación que abastecen al espacio costero de El Coco.

Finalmente se propuso un modelo de gestión integral en el manejo sostenible, administración y protección del recurso hidrogeológico, considerando las políticas y normativas nacionales, la legislación municipal y las directrices de los actores locales. 